\title{
Metode Sejarah Ibn Khaldun
}

\section{Saidun Derani*}

Abstract: Ibn Khaldun is a medieval Muslim scholar who was internationally known for his scientific reputation as well as his pioneered study of historical writing. This study offers a new method that not only relies on the honesty and truthfulness of the informant (news man), but also on the understanding of each civilization characteristics and the laws of nature (sunnatullah) that go with it in order for the public to be freed of false information in the history narrative. He also introduced new science called the science of al-Umran (al-ljitima' al-Basyari), which on the next period developed into a science of sociology, that focuses on community studies.

Kata Kunci: Muqaddimah, ilm al-Umran, al-ijtima' albasyari, dan sosiologi.

KESADARAN sejarah merupakan salah satu keunikan yang dimiliki manusia. Mengapa demikian, karena latar belakang tata nilai yang menjadi acuan suatu masyarakat sangat memberi pengaruh terhadap pola perilaku mereka. Man has no nature, what he has is history, demikian filsuf J. Ortega Y. Gasset mengatakan. ${ }^{1}$ Tetapi bagi sejarawan periode Renaissance, seperti Machiavelli, dan kebanyakan sejarawan moderen tidak demikian, mengapa? karena manusia memiliki kodrat sebab itu dia memiliki sejarah. ${ }^{2}$

Jurusan/Program Studi Sejarah dan Peradaban Islam Fakultas Adab dan Humaniora Universitas Islam Negeri (UIN) Syarif Hidayatullah Jakarta. E-mail: saidun_derani@yahoo.com. 
Dalam konteks ini, barangkali perlu direnungkan pernyataan Confusius study history if you would like divine the future dan Dyonisus history is philosophy teaching by examples. ${ }^{3}$ Salah satu wujud kesadaran sejarah adalah mempelajari, menelaah, dan mengkaji karya-karya yang dihasilkan para penulis sejarah sejak Socrates sampai masa kontemporer. Dimulai dari Herodotus ke sejarawan abad pertengahan, Ibn Khaldun, sampai sejarawan kontemporer, antara lain Burckhardt, Toynbee, Huizinga, dan Romein.

Pada hakikatnya para pemikir merupakan produk jamannya, yang dibatasi aspek geografis dan waktu. Tetapi sungguhpun dibatasi, pemikiran mereka(pendapat dan teori) mampu melampui batas-batas jaman dilihat dari aspek daya guna untuk menjelaskan problema masyarakat kontemporer sekarang. Sebab itu dari sisi inspirasi dan motivasi, para pemikir sosial, pemimpin (formal dan informal), dan decision maker, mencoba menggali kembali karya-karya mereka, yang mungkin masih bisa digunakan bagi kepenti- ngan umat manusia sekarang dan mendatang.

Di antara karya penting yang menjadi sumber pemikiran sejarah yang dikagumi sejarawan Barat era moderen, tetapi kurang diketahui sejarawan Muslim Indonesia (yang profesional) adalah karya Ibn Khaldun, Mugaddimah ${ }^{4}$ dan Kitab al-' Ibar. ${ }^{5}$ Mengapa Mugaddima $h^{6}$ yang kaya dengan teori dan ilmu (baru) tentang sejarah kemanusiaan dan kebudayaan banyak mendapat perhatian daripada al-'/bar. ${ }^{7}$ Tulisan ini ingin mengulas metode sejarah Ibn Khaldun. Siapakah Ibn Khaldun, apa definisi sejarah menurutnya, dan hubungan sosiologi dengan sejarah, yang disebutnya dengan ilmu Umran atau alljitma' al-Basyari, yaitu ilmu kemasyarakatan sebagai alat bantu sejarah.

\section{Mengenal Ibn Khaldun Le- bih Dekat.}

Ibn Khaldun ${ }^{8}$ dikenal sebagai sosok yang aktif dan kreatif, tidak hanya seorang teoritisi tetapi juga praktisi. Beliau memiliki pengalaman yang sangat luas dalam bidang politik di manca negara, 
antara lain Maghrib, Tunisia, Mesir, dan Spanyol sehingga para pengikut maupun lawannya memberi sebutan dengan gelar sebagai negarawan, diplomat, dan politisi. Beliau juga seorang hakim, pendidik, dan pemikir (ilmuwan), filsuf, dan penulis yang produktif. Karya monumentalnya $M u$ qaddimah dan Kitab al-'/bar' banyak menjadi rujukan kalangan pemikir moderen, khususnya pemikir Barat. Mengapa? ${ }^{10}$ karena di dalamnya terkandung ilmu-ilmu dan teoriteori baru tentang kemasyarakatan.

Ibn Khaldun" dilahirkan di Tunisia (1332-1406 M), masa awal menurunnya pamor kekuasaan politik dunia Islam dan mulai bangkitnya Eropa Yudea-Kristiani. la adalah manusia yang unik dan jenius.Samudera ilmunya menyebabkan perbedaan para Khalduni $^{12}$ dan pengagumnya menentukan posisinya dalam berbagai cabang ilmu pengetahuan. la dipandang perintis ilmu sosiologi dan filsafat sejarah. la juga mengkaji tematema yang berkaitan dengan antropologi, ekonomi, agama, politik, dan budaya.
Ibn Khaldun mendapat banyak perhatian para pemikir Barat moderen dan kemudian dunia Islam. ${ }^{13}$ Patut ditangisi bahwa kajian sarjana Muslim jauh dari memadai. Nurcholish Madjid, mengatakan: Mereka lebih mampu menelaah karya-karya bermutu seperti Ihya'nya al-Ghazali, tetapi secara intelektual tidak at home dengan karya-karya ilmiah semisal Muqaddimah Ibn Khaldun. ${ }^{14}$

Mungkin menghilangnya Muqaddimah dari dunia Islam menurut Wafi, karena kebekuan tradisi berpikir umat Islam waktu itu yang tidak mampu mengapresiasi ketinggian karya Ibn Khaldun di atas. Betul Ibn Khaldun banyak mengemukakan teori yang bisa diterima Barat, tetapi tidak dalam dunia Islam. Contoh, pendapatnya tentang tingkat manusia dicapai setelah melalui tahap kera, ${ }^{15}$ lalu teori 'asabjyah ${ }^{16}$ tentang perkembangan masyarakat dan negara. Bisa jadi istilah-istilah yang digunakan Ibn Khaldun ini termasuk ciri-ciri kehidupan masyarakat Jahiliyah yang harus dibuang dari komunitas Islam. Dalam bidang historiografi peran 
penting Ibn Khaldun dalam filsafat sejarah, baik aspek kritik maupun kontemplatifnya, tidak dikembangkan sejarawan Muslim sesudahnya. Effat alSarqawi mengatakan bahwa: Mereka tidak mengambil metodenya dalam mengkaji sejarah. Perhatian mereka hanya terbatas pada ide pencatatan peristiwa historis tanpa menegakkan kajian tentang sejarah di atas asas interpretasi fenomena-fenomena sejarah secara sosial dan kultural yang komprehensif. Jawaban riil terhadap problematika sejarah adalah para tokoh atau pahlawan sejarah. Sehingga karya mereka lebih diwarnai berita tentang para raja dan pembesar tanpa ada perhatian terhadap kondisi-kondisi masyarakat yang berhubungan erat dengannya, yang merupakan produk kultural kondisi-kondisi itu. ${ }^{17}$

Barangkali Barat yang lebih banyak mengikuti jejak Ibn Khaldun terutama dalam hal penulisan sejarah yang bercorak sosial dan kultural. Mereka memulainya setelah mengenal pemikiran sejarah Ibn Khaldun pada abad ke-19 M. Sedangkan para sejarawan
Muslim masih mengikuti tradisi historiografi rasionalis Barat abad $18 \mathrm{M}$, atau bahkan kembali ke tradisi historiografi tradisional pra Ibn Khaldun. Terkesan, kata Kuntowijoyo, ahli sejarah UGM Yogyakarta, sejarawan Muslim kurang apresiatif terhadap prestasi Ibn Khaldun dalam investigasi,kritisisme, dan metodologi sejarah. Sehingga dapat dibilang, bahwa Ibn Khaldun pemikir yang tidak memiliki pendahulu dan pengikut yang meneruskan pemikirannya dari kalangan Islam. ${ }^{18}$

\section{Pengertian Sejarah dan Metode Sejarah.}

Dalam kehidupan masyarakat sering dijumpai ungkapan, antara lain; mari kita belajar sejarah, sejarah selalu berulang, dan pengalaman sejarah. Dari ungkapan tersebut terlihat bahwa kata sejarah mempunyai banyak arti, misalnya cerita, sebuah rekonstruksi, kumpulan gejala empiris dalam masa lampau.

Sejarah memiliki dua pe-ngertian, yaitu: (1) Sejarah dalam arti subyektif ${ }^{19}$ atau sejarah sebagai sebuah gambaran; disebut juga history as 
written adalah cerita, uraian, hasil renungan pikiran seseorang (mind of man) yang merupakan hasil konstruksi secara narasi, berdasarkan atas hasil pandangan, pendekatan, teori, dan metode yang dianut (oleh seseorang) dari kumpulan gejala empiris masa lampau (pada kenyataannya bisa berupa cerita, hikayat, tambo dan sebagainya). (2) Sejarah dalam arti obyektif ${ }^{20}$ ialah sejarah dalam aktualitas (actuality).Jadi event' (kejadian) itu sendiri terlepas dari subyek. ${ }^{22}$ Setiap event tidak terus berlangsung, bahkan ada event tidak ditemukan lagi jejaknya.

Orang merekonstruksi kejadian yang telah terjadi (sejarah) biasanya tidak memiliki bahan yang cukup. Sebab itu dalam rekonstruksi bukan hanya pikiran yang berfungsi, tetapi juga imajinasi. Dari bahanbahan yang sedikit di anganangankan apa sebenarnya yang telah terjadi.

Sejarah tidak lain adalah penelusuran/pemeriksaan jejak. Malah ada yang berpendapat history as detective. Gejala yang ada sekarang ini sebenarnya merupakan jejak dari masa lampau. Jejak yang ideal dalam penulisan sejarah berupa sumber-sumber tertulis (bahasa, sastra), karena dapat dikomunikasikan dari kurun waktu yang berbeda. Sedangkan isi pesan di dalamnya tetap dan hidup. Dalam sejarah jejak ini disebut dengan fakta (fact). ${ }^{23}$

Kata history yang diekuivalen dengan sejarah dalam bahasa Indonesia terhimpun ada empat pengertian, yaitu: (1) sesuatu yang telah berlalu, suatu peristiwa, kejadian, (2) riwayat dari yang tersebut dalam poin satu, (3) semua pengetahuan tentang masa lalu, dan (4) ilmu yang berusaha menentukan dan mewariskan pengetahuan. ${ }^{24}$

Bagi Murtadha Muththahhari, ilmuwan Muslim Iran abad 20, sejarah adalah, pertama, sejarah sebagai pengetahuan tentang kejadiankejadian dan keadaan kemanusiaan masa lampau dalam kaitannya dengan keadaan masa kini, kedua, pengetahuan tentang hukum-hukum yang tampak menguasai kehidupan masa lalu yang didapat melalui penelaahan dan analisis atas peristiwa masa lalu, baik sosial, politik, ekonomi, 
maupun agama dan budaya dari suatu bangsa, negara. ${ }^{25}$

Perhatikan pengertian sejarah menurut Hasan Utsman dan Ibn Khaldun berikut ini.Mayoritas sejarawan membatasi arti sejarah atos penelitian dan eksplorasi peristiwa masa lampau. Hal itu seperti diindikasikan lafal historia yang diambil dari kata Yunani klasik dalam artian semua yang berkaitan dengan manusia sejak ia mewariskan peninggalannya pada batu dan bumi, apakah warisan itu berupa cataton atau gambar, yang menginfokan peristiwa yang terjadi. Terkadang lafal sejarah menunjukkan semua kejadian yang dilakukan para pahlawan (heroes) dan bangsa-bangsa, dari sejak kuno sampai sekarang (waktu dan tempat). Dalam bahasa Arab kata tarikh, ta'rikh, dan taurikh berarti pemberitahuan ter hadap waktu, terkadang kata tarikh al-syai menunjukkan arti tujuan dan masa berakhirnya, termasuk di dalamnya peristiwa dan kejadian besar yang sejalan. Sejarah (tarikh) adalah suatu seni yang membahas tentang kejadian waktu dari segi spesifikasi dan pe- nentuan waktunya, temanya manusia dan waktu, permasalahannya adalah keadaan yang menguraikan bagianbagian ruang lingkup situasi yang terjadi pada manu-sia dan dalam suatu waktu. ${ }^{26}$ Ibn Khaldun mengatakan: sejarah pada hakikatnya adalah catatan tentang masyarakat manusia. Sejarah itu sendiri identik dengan peradaban dunia; tentang perubahan yang terjadi pada peradaban itu, seperti keliaran (nomaden), keramahtamahan, dan solidaritas golongan ('asabiyah); tentang revolusi dan pemberontakan golongan rakyat melawan yang lain dengan akibat timbulnya kerajaan-kerajaan dan negara-negara dengan berbagai macam tingkatannya; tentang kegiatan dan kedudukan orang, baik untuk mencapai penghidupan maupun dalam ilmu pengetahuan dan teknologi; dan pada umumnya tentang segala perubahan yang terjadi dalam peradaban karena peradaban itu. ${ }^{27}$

Adapun metode sejarah yang dipakai sejarawan memiliki dua pengertian, yaitu melihat dari aspek sekumpulan prinsip dan aturan, sedang 
aspek lain ditilik dari segi prosesnya. ${ }^{23}$ Jadi metode sejarah adalah historical method is a systematic body of principles - and rules designed to aid affectively in gathering the source-materials of history, apprajsing the critically and presenting a synthesis (generally in written form) of the results achieved. Bisa juga merupakan sekumpulan prinsip dan aturan yang sistematik dengan daya guna untuk memberikan bantuan secara efektif dalam usaha mengumpulkan bahanbahan bagi sejarah, menilai secara kritis dan kemudian menyajikan suatu sintesis hasil-hasilnya (tertulis). ${ }^{29}$

Proses metode sejarah ada 4 tahapan. Pertama, heuristik, yaitu proses mencari untuk menemukan sumbersumber. Kedua, diadakan kritik, baik ekstern maupun intern. Kritik ekstem menyangkut dokumen-dokumen, apakah dokumen itu yang memang dibutuhkan atau tidak, palsu atau tidak, apakah utuh atau sudah diubah. Pasca itu diadakan kritik intern untuk menilai isinya. Tujuannya untuk menyeleksi data menjadi fakta. Ketiga, melakukan usa- ha merangkai fakta menjadi sesuatu yang masuk akal (interpretasi). Keempat, historiografi, yaitu penulisan sejarah. Tujuannya untuk merangkai fakta menjadi kisah sejarah. ${ }^{30}$

Metode Sejarah Ibn Khaldun

Bagi Ibn Khaldun sejarah itu suatu ilmu yang harus dikaji. Jadi bukan sebagai kabar dan cerita saja, tetapi hanus dilihat secara ilmiah. ${ }^{31} \mathrm{Se}$ bab itu Ibn Khaldun mencoba melahirkan cara-cara untuk memahami dan menulis sejarah yang tidak dilakukan para sejarawan sebelumnya.

la mengemukakan prinsip-prinsip tentang sistem baru dan mengenalkan nilai serta metode sejarah dengan jelas. la membuktikan kesalahan pandangan dan kelemahan para sejarawan. Mengapa hal itu terjadi, menurutnya antara lain karena faktor semangat terlibat (subyektivitas), fanatisme, prasangka, dan keinginan untuk menyenangkan penguasa. Ibn Khaldun menambahkan, bahwa para sejarawan menerima informasi sejarah tanpa mengadakan investigasi dan kritik.Ada investigasi yang 
benar dan verifikasi berdasarkan metode Hadis, tetapi tidak mengerti tabiat peradaban. Inilah sebabnya mengapa sejarawan tidak mampu memahami gejala dan peristiwa sejarah. ${ }^{32}$

\section{Metode Kritik Internal dan Eksternal}

Ibn Khaldun menjelaskan bahwa dalam penulisan sejarah membutuhkan metode khusus atau ilmu bantu untuk memahaminya. Suatu ketelitian dari aspek kritik internal maupun eksternal sangat diperlukan, jadi tidak bergantung pada sumber sejarah saja atau hanya mempercayai pembawa sumber berita. la menekankan pentingnya mengetahui watak peradaban dunia agar tidak tergelincir dari kesalahan dalam menulis sejarah. Ia mengatakan dalam Mugaddimahnya: ketahuilah, bahwa sejarah merupakan disiplin ilmu yang sangat banyak dan memiliki sasaran mulia. penulisan sejarah membutuhkan sumber yang beragam dan pengetahuan yang bermacam-macam. la membutuhkan perhitungan yang tepat dan kete- kunan. Kedua sifat ini membawa sejarawan kepada kebenaran dan menyelamatkannya dari berbagai ketergelinciran dan kesalahan. Sebab, apabila catatan sejarah mereka hanya didasarkan kepada bentuk nukilan dan tidak didasarkan pada pengetahuan yang jelas tentang prinsipprinsip yang ditarik dari kebiasaan tentang fakta-fakta politik yang fundamental, peradaban, dan segala hal ikiwwal yang terjadi dalam kehidupan manusia, selanjutnya. apabila sejarah tidak diperbandingkan antara materinya yang gaib dengan yang nyata, yang ba$n u$ dengan yang kuna, past akan ditemukan penghalang, ketergelinciran, dan kekhilafan dalam berita sejarah itu. ${ }^{33}$

Pada hab lain, ia melanjutkan: Dan penyelidikannya Cyaitu tentang kejadian-kejadian yang diceritakan ituj bisa dilaksanakan hanya dalam cahaya pengetahuan tentang watak peradaban.Inilah metode terbaik dan paling meya. kinkan dalam usaha menyeljdiki informasi sejarah secara kritis dan untuk digunakan dalam usaha memisahkan kebenaran yang terkandung di 
dalam informasi itu dari kebohongannya. Hal ini dilakukan sebelum berusaha dilakukannya kritik terhadap para perawi. Apabila kejadian yang diceritakan itu tidak mungkin, maka tidak perlu lagi diadakan penyelidikan yang kritis terhadap pribadi orang yang menceritakan cerita-cerita itu [ta'dil wa tajrih]. ${ }^{34}$

Dari uraian di atas menunjukkan bahwa Ibn Khaldun juga menggunakan metode kritik jarh wa ta'dil yang merupakan prinsip-prinsip dalam ilmu Musthalah Hadis. Metode utama baginya ialah pengkajian berita-berita sejarah dengan menggunakan hukum-hukum yang mengendalikan alam dan masyarakat. Jadi, bilamana antara beritaberita sejarah dan hukum-hukum tersebut dapat beriringan, maka berita-berita itu adalah benar. Sebaliknya, bilamana antara berita dan hukum ada pertentangan, maka berita itu ditolak meski rangkaian penuturnya dapat diterima.

Pada bagian lain, ia melanjutkan: kejujuran dan kebenarannya haruslah diuji dengan mempertimbangkan ke- sesuaian atau ketidaksesuaian informasi yang dinukil dengan kondisi umum. Karena itu, meneliti kemungkinan atau ketidakmungkinan peristiwa yang diberitakan harus didahulukan. Hal ini lebih penting dan diprionitaskan daripada meneliti pribadi yang menukilnya. Dengan kata lain, nilai dari perintah dan larangan terletak pada perintah dan larangan itu sendiri. Sedangkan nilai informasi suatu penistiwa terletak pada kesesuaian laporan historis dengan kondisi umum. ${ }^{35}$

Dalam uraian ini Ibn Khaldun memberikan nasihat kepada para sejarawan agar tidak mengikuti cara-cara investigasi dan verifikasi kecuali mereka sudah yakin bahwa apakah gejala-gejala atau peristiwa sejarah sesuai dengan tabiat peradaban atau tidak. Metode ini disebut dengan metode kritik eksternal.

Apabila demikian halnya maka metode normatif untuk membedakan kebenaran dari kebatilan yang terdapat dalam informasi sejarah di atas dasar-dasar kemungkinan atau ketidakmungkinan yang melekat menjadi sifatnya terdapat 
dalam mempelajari masyarakat umat manusia lijtima basyani]. Yang terakhir ini identik dengan peradaban ['umran, sivilisasij. ${ }^{36}$

Perbedaan kritik intern dan ekstern menurut Ibn Khaldun dapat dijelaskan dengan bantuan 2 perbedaan primer dan 4 perbedaan sekunder gejala sejarah. Perbedaan pertama adalah bentuk eksternal sejarah yang merupakan kumpulan informasi tentang peristiwa sejarah pada waktu dan tempat tertentu. Kedua adalah makna internal sejarah yaitu investigasi rasional teoritis tentang asal usul dan sebab-sebab yang disebut dengan usaha-usaha ilmiah. ${ }^{37}$

Sedangkan dalam 4 perbedaan sekunder, Ibn Khaldun mengalihkan karakter sejarah kepada para sejarawan dan membedakannya. Di antara mereka disebut sebagai ahli sejarah dan pemimpin yang dihormati dan diterima dan sebagian dikelompokkan sebagai plagiat dan penulis ikhtisar sejarah. Karya-karya sejarah dua kelompok itu menunjukkan perbedaan dalam metode mereka. Ibn Khaldun membedakan metode peneli- tian kritis dengan nagli atau menukil. Ini yang mendorongnya membedakan antara dua sikap mental antara mahasiswa sejarah yang memiliki sikap kritis (naqid) yang menelaah asal usul, tabiat, dan sebab peristiwa sejarah dan mengkajinya berdasarkan latar belakang sifat umumnya (yang tetap dan berubah), dan yang tidak memiliki sikap kritis (literal, bodoh, balid) yang mengumpulkan informaasi tanpa memperhatikan asal usul, tabiat, atau sebabnya. ${ }^{38}$

\section{Perbedaan Metode Peneli- tian .Berita-Berita Sejarah dan Keagamaan \\ Ibn Khaldun tidak ber-} henti pada kritik terhadap metode penuturan berita historis. Beliau juc - menyusun suatu metode dalam meneliti berita dengan menelaah kebenaran informan dan kredibilitasnya dengan merujuk sistem ahli Hadis, jarh wa ta'dil. Namun ia memberi catatan, bahwa ada perbedaan substansial antara metode penelitian berita keagamaan dan sejarah. ${ }^{39} \mathrm{Me}$ ngapa demikian, karena hukum yang didasarkan pada berita keagamaan merupakan 
petunjuk legal, ${ }^{40}$ hukum normatif menentukan kewajiban bagi yang terkena kewajiban dan memerintahkannya untuk melakukan atau meninggalkan suatu perbuatan.Opini kebenaran suatu berita sudah cukup untuk mewajibkan suatu perbuatan dengan semua hal yang berkenaan dengannya sesuai dengan prinsipprinsip agama tanpa butuh pada keyakinan terhadap berita tersebut. Karena itu mereka mengatakan, bahwa jarh wa ta'dil saja sudah cukup untuk memastikan suatu perbuatan. ${ }^{41}$ Jadi seorang yang mengkaji informasi keagamaan tidak perlu mengetahui hukum sosial atau watak yang muncul dalam peradaban, sebab wahyu ilahi merupakan satu-satunya sumber informasi keagamaan. ${ }^{42}$ Karenanya informasi seperti itu harus diterima sebagaimana adanya tanpa dimanipulasi atau diubah oleh siapapun. Hanya dengan cara demikian seseorang meneliti integritas dan kebenaran informasi keagamaan. ${ }^{43}$

Sedangkan hukum yang terkandung dalam berita historis berhubungan dengan ke- jadian-kejadian aktual (waqi'at). ${ }^{44}$ Hukum informatif tidak memerintahkan sesuatu dan tidak mewajibkan suatu perbuatan, atau mengharuskan untuk meninggalkan sesuatu. Berita ini tidak mempunyai tujuan kecuali untuk mengukuhkan suatu kenyataan. Sebab itu berita tersebut harus dievaluasi berdasarkan keseiringannya atau ketidakseiringannya dengan kenyataan. Dengan demikian itu tidak hanya dengan jarh wa ta'dil, (dengan meyakinkan adil dan tidaknya para penutur), tetapi ia membutuhkan suatu tinjauan yang lebih luas dan penelitian yang mendalam. ${ }^{45} \mathrm{Jadi}$ laporan sejarah pada sisi lain bukanlah perintah melainkan statemen affirmatif atau negatif suatu peristiwa. Pernyataan ini benar atau salah ada dalam dirinya sendiri. Ini adalah definisi gramatika dan logika.

Metode kritik mengenai pernyataan di atas seharusnya dimulai dengan pernyataan apakah kejadian itu terjadi atau tidak. Ini adalah pernyataan primer, sebab sekali ketidakmungkinan suatu peristiwa terjadi, maka tidak berguna dilakukan kritik.Jika ilmu mus- 
talah hadis (the science of tradition) membatasi dirinya pada authority-criticism, maka sejarah membutuhkan keduaduanya, watak segala sesuatu dan authority-criticism.

Dengan demikian sejarah membutuhkan dua ilmu bantu; ilmu budaya yang berhubungan dengan kejadian sejarah dan authority-criticism yang berhubungan dengan kompetensi, pengetahuan,dan motif yang berkaitan dengan beritaan kejadian sejarah. ${ }^{46}$

\section{Pedekatan Multidimens: dalam Penulisan Sejarah}

Ibn Khaldun adalah sejarawan pertama yang berusaha menggunakan berbagai pendekakatan disiplin ilmu dalam penulisan sejarah, kemudian diteruskan dalam historiografi Islam sampai pengaruh moderen merambah dunia Islam. ${ }^{47}$ Hal ini terlihat dalam keberhasilan aplikasinya bagi penulisan sejarah dengan pendekatan politis dan sosiologis sebagai ilmu tersendiri yang menggabungkan masa lalu dengan kekinian dengan proses yang terus berlangsung. ${ }^{48}$ Bagaimanakah konsep multidimentional approaches
Ibn Khaldun dalam penulisan sejarah ini.

Dalam Mugaddimah Ibn Khaldun menerangkan bahwa penulisan sejarah harus dilihat dengan berbagai disiplin ilmu, antara lain memahami watak peradaban, kondisi masyarakat, pertumbuhan penduduk, aktivitas ekonomi, dan kemajuan ilmu pengetahuan dan industri. Perhatikan uraiannya berikut ini: Ketahuilah bahwa sejarah adalah disiplin ilmu yang memiliki banyak ragam pendekatan (mazhab).49 Aspek penggunaa: ya sangat banyak dan memiliki sasaran yang berbeda. Sejarah membutuhkan sumber yang beragam,serta membutuhkan analisis yang cermat dan ketekunan (konsisten). Kedua sifat ini membarva sejarawan kepada kebenaran dan menyelamatkannya dari berbagai ketergelinciran dan kesalahan. ${ }^{50}$

Ibn Khaldun mengkritisi para penukil berita yang tanpa meneliti asal usul sumber beritanya, sejarawan yang tidak memahami perubahan jaman, kondisi sosial politik, dan jiwa jaman, telah terbukti kelemahan dan kesalahan nukilan-nukilannya. Ini berarti 
gejala sejarah akan lebih dipahami jika dibantu dengan ilmu-ilmu tentang kebudayaan, sosial, politik, geografi, demografi, ekonomi, dan militer.

\section{Subyektivitas dalam Penu- lisan Sejarah Menurut Ibn Khaldun}

Manurut Ibn Khaldun ada berbagai sebab yang memunculkan subyektivitas dalam penulisan sejarah. Pertama, anda harus tahu bahwa semua berita sesuai dengan sifatnya dapat terkena kesalahan, bahkan berita itu sendiri bisa mengandung faktor-fakor penyebab kesalahan. Penyebabnya, sikap memihak kepada suatu kepercayaan atau pendapat. Jika pikiran dalam keadaan netral, settap orang biasanya ketika menerima sebuah informasi akan meneliti dan menimbangnya sampai ditemukan kebenaran dan ketidakbenaran. Jika bilamana pikiran seseorang itu berat sebelah kepada salah satu pendapat atau kepercayaan, maka ia akan berpihak kepada keterangan-keterangan yang menguntungkan pendapat atau kepercayaannya. Dalam konteks ini sikap memihak akan menutup kebenara dan mencegah penelitian, kemudian cenderung melakukan kesalahan. ${ }^{51}$

Jadi kesalahan pertama dalam penulisan sejarah kata Ibn Khaldun adalah kecenderungan orang untuk menerima begitu saja berita yang sesuai dengan pendapat atau kepercayaannya tanpa meneliti lebih jauh kebenarannya (aspek psikologis). Mengapa demikian, karena opini yang berkembang, sebagaimana dikatakan al-Husri, berupa paham yang mengalahkan pemikiran orang sehingga memengaruhi penilaian mereka. Kedua,kepercayaan yang berlebihan kepada informan, padahal penuturan apapun seharusnya baru bisa diterima jika telah melalui proses ta'dil wa tajih. ${ }^{52}$ Bagi al-Husri, penyebab kedua ini tidak dipaparkan Ibn Khaldun secara rinct. Penyebutan ta'dil wa tajih menunjukkan bahwa kesaitahan yang dilakukan sejaráwan akibat terlalu percaya kepada penutur. Tidak menutup kemungkinan informan itu berdusta atau mengadaada. Sebab itu, sejarawan harus benar-benar selektif dan 
krtitis menerima informasi sehingga tidak terjebak dalam kesalahan. Persoalannya adalah apakah metode ta'dil wa tajrih merupakan langkah pertama dalam meneliti berita?

Ibn Khaldun dalam $M u$ gaddimah mengatakan bahwa ta'dil wa tajrih adalah langkah kedua.Sedangkan langkah per tama adalah menilai apakah isi berita itu merupakan hal yang mungkin atau mustahil. Dan penelitian tentang keadilan dan kejujuran para penutur tidak dilakukan kecuali setelah diketahui bahwa isi benita itu sendiri merupakan hal yang mungkin terjadi atau tidak sama sekali. Jika mustahil terjadi, maka tidak ada gunanya dilakukan ta'dil wa tajih. $^{53}$

Ketiga, ketidaksanggupan memahami apa yang sebenarnya terjadi. ${ }^{54}$ Kebanyakan pencatat sejarah jatuh dalam kesalahan karena mereka tidak dapat memahami maksud sebenarnya dari apa yang dilihat dan didengarnya. Selain itu mereka mengaitkan berita itu menurut apa yang dipikirkan dan dipersepsikan, sehingga mereka tergelincir ke lubang kekeliruan. ${ }^{55}$
Sebab ketiga ini menurut Sathi' meliputi mengamatan psikologis yang benar. Jadi terkadang pencatat sejarah benar dalam mencatat suatu berita, tetapi keliru dalam memahaminya. la menulis berita berdasarkan persepsi yang berbeda dengan hakikatnya padahal persepsinya itu salah.

Keempat, kepercayaan yang salah kepada kebenaran. Pada umumnya hal ini sering terjadi dalam bentuk terlalu memutlakkan kebenaran yang disampaikan penutur berita. Dengan kata lain, ..jarawan menuturkan berita yang keliru dengan keyakinan bahwa berita itu merupakan kebenaran sehingga tidak ada penyeleksian. Sebab yang keempat ini dapat dirujuk kepada sebab yang kedua ${ }^{56}$

Kelima, ketidaksanggupan menempatkan dengan tepat suatu peristiwa dan hubungannya dengan kejadian yang sebenarnya karena kabur dan kompleksnya keadaan. Pencatat merasa puas memaparkan peristiwa seperti yang dilihatnya saja akibatnya pemutarbalikkan kejadian itu sendiri. ${ }^{57}$ 
Sebab kelima ini sekitar kekaburan dan kerumitan peristiwa dan berita. Atau bisa juga sebagian orang tidak bertanggung jawab berupaya menipu orang dengan menciptakan beberapa peristiwa. $\mathrm{Da}$ lam konteks ini jika sejarawan tidak menyadari pemutarbalikkan berita itu, maka dengan tidak sengaja ia telah menuturkan informasi yang benar dalam penuturannya. ${ }^{58}$

Keenam, keinginan untuk mengambil hati orang yang berkedudukan tinggi dengan cara memuji, menyiarkan kemasyhuran, membujuk, dan menganggap baik setiap perbuatannya serta memberi penafsiran yang selalu positif apa yang mereka lakukan. Hal demikian akan melahirkan kekeliruan suatu kejadian sejarah. Tambahan, memang kecenderungan manusia senang dipuji dan termotivasi untuk mencapai kesenangan berupa harta dan kedudukan (kehormatan). Mereka tidak mencari kelakuan yang baik atau berupaya mendapatkan kebaikan dari orang yang baik. ${ }^{69}$ Jika sejarawan berupaya mendekatkan diri kepada para penguasa/pejabat tinggi demi mendapat kepentingan dunia, maka akan mendorongnya untuk menyebarkan berita bohong tentang para penguasa itu.

Ketujuh, menurut lbn Khaldun ${ }^{60}$ merupakan sebab yang paling penting meski dalam Mugaddimah diletakkan pada urutan terakhir.Adapun sebab ketujuh ini adalah tidak mengetahui hukum-hukum watak dan perubahan masyarakat. Padahal segala sesuatu baik benda maupun perbuatan tunduk kepada hukum watak dan perubahan. Kalau pendengar memahami watak perittwa dan perubahan yang terjadi akan membantunya melebihi apa pun dalam menguraikan kisah sebuah peristiwa yang dicatatnya dan untuk memilah kebenaran dari kebohongan yang terkandung dalam catatan itu. ${ }^{61}$

Menurut Ibn Khaldun setiap fenomena dalam wujud, baik fenomena alam maupun sosial, memiliki hukum-hukum pengendaliannya, baik dalam keadaan mapan maupun berubah. Hukum ini hendaknya diketahui para sejarawan agar mereka mampu 
membedakan antara berita benar dan bohong.

Menurut al-Husri terdapat dua sebab lagi yang tidak dikemukakan Ibn Khaldun. Sebab yang pertama menurut Ibn Khaldun ialah: Seringkali para sejarawan, ahli tafsir, dan tokoh penutur terjatuh dalam kesalahan pada pemahaman berita dan peristiwa. Karena mereka hanya mendasarkan diri pada sumber berita semata terlepas berita itu salah atau benar. Mereka tidak mengembalikannya kepada asal-usulnya dan menganalogikannya dengan peristiva yang sama. Selain itu mereka juga tidak mengujinya dengan ukuran hikmahnya dan berhenti pada watak-watak yang ada serta memperkuat penelitian dan pengkajian terhadap berita-berita itu sehingga terjadi penyimpangan kebenaran. Lebih jauh lagi mereka memberi kesempatan yang seluasluasnya kepada khayal (imajinasi) mereka karena mengikuti bisikan yang berlebihan dan melintasi batasan pengalaman yang biasa jika mendiskusikan soal tentara dan kekayaan negeri-negeri pada periode mereka atau masa lampau yang lebih dekat. ${ }^{62}$

Sedangkan sebab kedua yang beliau sebut dalam Mugaddimah ialah analogi secara mutlak masa lampau atas masa kini. Ibn Khaldun menjelaskan sebagai berikut: Terkadang pendengar menerima khabar kebanyakan orang masa lampau dan kurang memahami perubahan keadaan. Maka berita itu pun ia samakan dengan apa yang dia saksikan padahal kadang-kadang ada perbedaan di antara keduanya jauh sekali.skibatnya, sejarawan terjatuh ke dalam lubang kekelinuan. Ini disebabkan keadaan alam bangsa-bangsa, kebiasaan, dan agama mereka tidak selalu pada alur dan jalan yang sama. ${ }^{63}$

Perscalannya, apakah sarana untuk meneliti berita sejarah sehingga dapat memilah dan memilih antara berita benar dan berita bohong. Ibn Khaldun menyebutkan dalam kaitan ini, ada dua sarana, pertama,pemikiran yang mendalam atas kejadian-kejadian yang dituturkan. Kedua, pengkajian terhadap peringkat kebenaran dan kejujuran informan. Sarana pertama dapat 
diwujudkan dengan ilmu budaya. Sedang sarana kedua direalisasikan dengan metode ta'dil wa tajrih.

Tentang penelitian berita sejarah, Ibn Khaldun memaparkan: Ini dapat dilakukan dengan mengetahui watak-watak masyarakat. Inilah metode yang sebaik-baiknya dan yang paling menjamin kebenaran untuk meneliti benita-berita itu dari kesalahan. Langkah ini dilakukan sebelum upaya meneliti berita-berita para informannya dengan menyelidiki terhadap mereka (ta'dil dan tajrih). Sebab kritik baru dijalankan setelah yakin apakah peristiwa yang dituturkan itu sendiri tidak mungkin, maka tidak perlu lagi dilakukan penyelidikan terhadap para informan kejadian itu. ${ }^{64}$

\section{Obyektivitas dalam Penu-} lisan Sejarah

Ibn Khaldun menyadari adanya kekurangan mengenai kriteria kebenaran berita sejarah, dengan membiarkan masuknya berbagai penyakit dalam penulisan kisah sejarah. Para sejarawan mendapat kritikan sangat tajam karena faktor kebohongan,semangat ter- libat dalam partai, terpukau cerita fantastis (kepahlawanan), dan niat untuk mengambil muka (penjilat).

Latar belakang hal-hal inilah yang mendorong lbn Khaldun berusaha maksimal memperbaiki dan mengembangkan alat atau metode yang memungkinkannya untuk meyakinkan kebenaran informasi dalam sejarah. Beliau berpendapat bahwa penelitian terhadap khabar (kisah sejarah) dengan sendirinya diinvestigasi memakai alat yang memastikan apakah kebenaran berita itu mungkin atau tidak. $^{65}$

Selain meyakinkan kemungkinan kebenaran peristiwa sejarah, beliau juga memberikan penjelasan ke arah obyektivitas sejarah di antaranya: 1. Sejarawan harus membebaskan dirinya dari ambisi, hawa nafsu, fanatisme, dan faktor penyimpang kebenaran.la hendaknya tampil dalam interpretasi sejarahnya tanpa konsep sebelumnya dan diwajibkan untuk memiliki perhatian besar dalam meneliti dan menyaring setiap berita yang diliputi keraguan, fanatisme golongan, atau me- 
muji seseorang yang dianggap besar. ${ }^{66}$ 2. Sejarawan harus memahami ilmu fisika, hukum, dan membuang jauh semua yang tidak dibenarkan menurut hukum tersebut. ${ }^{67} 3$. Ibn Khaldun melahirkan ilmu baru sosiologi untuk memahami sejarah. Untuk itu sejarawan harus memahami ilmmu-ilmu mengenai kemasyarakatan ini agar mampu membedakan antara yang benar dan salah, dalam memahami sejarah.

Dengan ilmu ini pula sejarawan bisa membedakan mana yang mungkin dan yang tidak mungkin dari berita sejarah. ${ }^{68} 4$. Pikiran harus netral. Sebab dengan pikiran netral, setiap orang ketika menerima informasi akan menyelidiki dan menimbangnya terlebih dahulu sampai dapat menyeleksi kebenarannya. ${ }^{69}$ 5. Sejarawan harus meneliti dan menelaah secara mendalam kebenaran berita sejarah dengan kritis, yaitu ta'dil wa tajnih. Ini bukan metode utama Ibn Khaldun, karena beliau lebih menekankan kepada pemahaman watak setiap peradaban, tabiat masyarakat, dan hukum alam. 6. Sejarawan membutuhkan pengeta. huan tentang prinsip politik, tabiat segala yang ada, perbedaan bangsa, tempat, periode dalam hubungannya dengan sistem kehidupan (way of Iffe), nilai akhlak, kebiasaan, sekte, mazhab, dan segala hal ikhwal lainnya. Sejarawan perlu juga memiliki pengetahuan bandingan tentang situasi dan kondisi semua aspek ini. 7. Sejarawan harus membandingkan kesamaan, dan membedakan keadaan kini dan masa lampau. la harus mengetahui sebab timbulnya kesamaan dalam beberapa situasi dan timbulnya perbedaan dalam situasi lainnya. Ia harus mengetahuai perbedaan sumber dan awal lahirnya negara, millah (kelompok agama) sebagaimana ia mengetahui perbec'zan sumber dan awal lahirnya alasan dan dorongan yang membuat semua itu terbentuk.

Dengan demikian, maka sejarawan harus mengetahui keadaan dan sejarah orangorang yang mendukungnya dengan tujuan untuk melengkapi sebab terjadinya masingmasing peristiwa. Dalam konteks inilah, pentingnya cek dan ricek berita yang dinukil 
sejarawan dengan prinsip dasar yang disebutkan tadi.

\section{Sosiologi dan Sejarah}

Berbeda dengan sejarawan Muslim sebelumnya, Ibn Khaldun memandang sejarah sebagai ilmu dengan kajian yang bernilai bukan sekedar cerita. Beliau memakai metode (baru) dalam menjelaskan kebenaran sejarah. Kajian dan refleksinya telah mengantarkannya menciptakan filsafat sosial. Dalam Mugaddimah diketahui penjelasan itu yang menjadi karya sejarah mandiri karena orisinalitasnya, berisi metode baru untuk memahami dan menjelaskan fenomena sosial. Karya ini memberikan informasi kepada pembaca bagaimana memahami, mengkritisi, dan menganalisis sejarah secara benar. ${ }^{70}$

Ibn Khaldun menjelaskan kajian baru ini seba!jai ilmu yang independen dengan subyek khusus sosiologi dan masyarakat (manusia) serta masalah khusus yang dimaksudkan untuk menerangkan semua fenomena dan kondisi yang melekat padanya. ${ }^{71}$ Ibn Khaldun menginformasikan kepada kita bahwa ilmu itu adalah ilmu baru dengan me-tode yang asing dan memilikj manfaat yang besar. ${ }^{72}$ Sebab terpenting yang mendorong Ibn Khaldun menciptakan ilmu barunya, sosiologi, adalah keinginannya yang penuh semangat untuk membebaskan analisis sejarah dari berita bohong.

Di samping itu tidak kalah pentingnya dorongan pribadinya untuk menciptakan alat yang dapat digunakan ahli-ahli bahasa dan pengarang yang terjun dalam dunia ilmu sejarah untuk bisa membedakan berita yang benar dan bohong, terkait dengan gejala sosial kemasyarakatan. Semua usaha, pikiran, dan analisis sejarah yang mereka lakukan hanya terpusat pada berita-berita obyektif dan faktual, yaitu berita yang mungkin terjadi dalam masalah (peristiwa) yang dialami manusia. $^{73}$

Ibn Khaldun melihat karya sejarah yang telah ditulis sebelumnya telah diselimuti berita yang tidak obyektif. la berpendapat, sudah kewajibannya untuk membebaskan sejarah dari berita semacam itu sehingga dapat memberi- 
kan gambaran yang obyektif tentang hal ihwal masyarakat serta tidak tercampur dalam pikiran manusia antara fakta yang obyektif dan hal ihwal yang tidak benar. ${ }^{74}$

Ilmu baru ini, yang lbn Khaldun ciptakan, untuk memahami dan mengkaji sejarah, memiliki manfaat yang besar. Dalam penjelasannya itu dikatakan bahwa ilmu baru tersebut untuk membedakan yang benar dan salah dalam sejarah dan untuk memperlihatkan kemungkinan dan ketidakmungkinan peristiwa sejarah itu terjadi. Dengan memperhatikan masyarakat yang merupakan kajian sosiologi untuk membedakan kondisikondisi yang berbeda yang melekat padanya dan dalam tabiatnya. Dengan cara ini kita menggunakan ilmu yang membedakan mana yang benar dari yang salah dalam sejarah yang didukung metode dan bukti yang tidak diragukan. Itulah usaha Ibn Khaldun untuk memahami sejarah, yang ilmu baru itu disebut alUmran atau al-Jjtima al-Basyari. ${ }^{75}$

\section{Kesimpulan}

Uraian di atas menjelaskan corak metode sejarah Ibn Khaldun yang dimaksudkan penciptaannya untuk membebaskan masyarakat dari informasi-informasi bohong gejalagejala historis.

Metode sejarahnya tidak hanya menyandarkan kejujuran dan kebenaran informan, tetapi lebih jauh lagi para sejarawan harus memahami watak setiap peradaban dan hukum alam (nature of law/sunnatullah). Dalam konteks ini, setiap peristiwa sejarah harus dilihat dari berbagi dimensi dengan ilmu bantu dalam penulisannya agar mereka menemukan obyektivitas dalam historiogarfinya.

\section{Catatan Akhir:}

1. Makalah Menteri Pendidikan dan Kebudyaan pada Seminar $\mathrm{Na}$ sional Sastra dan Sejarah Pajajaran, Bogor, 11 Nopember 1991 , h.1.

2. Emst Cassirer, Manusia dan Kebudayaan: Sebuah Esei tentang Manusia, terj. Alois A. Nugroho, Jakarta, Gramedia, 1990, Cet. ke-2, h. 260.

3. Makalah Menteri... op. cit., h. 2.

4. Buku Muqaddimah pada awalnya tidak dimaksudkan sebagai karya yang berdiri sendiri, tetapi merupakan bagian dari karya 
yang lebih besar tentang sejarah, yaitu buku Ibar. Kendati demikian, dalam perkembangan selanjutnya Ibn Khaldun semasa hidupnya telah menempatkan $\mathrm{Mu}$ gaddimah sebagai karya yang mandiri, terlepas dari buku lbar.

5. Judul lengkapnya adalah Kitäb al-'loar wa Díwän al-Mubtada' wa al-Khabar fi Ayyam al-'Arab wa al-Ajam wa al-Barbar wa Man Asarahum min Dzawi alSultān al-Akbar. F. Rosenthal menerjemahkan judul itu ke bahasa Inggris Book of Lessons and Archive of Early and Subsequent History, Dealing with the Political. Events Conceming the Arabs, Non-Arabs, and Berbers. and the Supreme Rulers Who Were Contemporery with Them (Buku Suri Teladan dan Catatan tentang Kejadian-kejadian Masa Lalu dan Perkembangan Selanjutnya mengenai Sejarah Arab, Non-Arab, dan Penguasa-Penguasa Besar Yang Semasa dengan Mereka). Patut diketahui bahwa karya ini sudah diterjemahkan ke dalam bahasa Jerman dan Perancis.

6. Mugaddimah, secara etimologis berarti Pendahuluan. Mengapa buku ini penting, karena: (1) bagian lain dari buku /baritu. jika dibandingkan dengan $M u$ gaddimah belum memasyarakat, (2) ketinggian dan bobot teori dalam Mugaddimah tidak lagi ditemukan dalam Ibar, (3) bagian bar terbatas nuang lingkup permasalahannya jika disanding dengan Muqaddimah, yang isinya terfokus kepada sejarah bangsa Arab dan bagian ketiga berisi bangsa Berter di Afrika Utara. A.
Rahman Zainudin, Kekuasaan dan Negara: Pemikiran Politik Ibn Khaldun, Jakarta, Gramedia, 1992, Cet. ke-1, h. 17.

7. Buku ini berdasarkan keterangan Ibn Khaldun sendiri, terdiri atas Pendahuluan dan ada 3 jilid. Buku pertama tentang kehidupan manusia dalam masyarakat, masalah kekuasaan, pemerintahan, penghasilan, mata penghidupan, iptek, dan sebab akibat yang ditimbulkannya. Buku kedua berisi sejarah bangsa Arab dan bangsa-bangsa lain yang sejaman dengan mereka. Buku ketiga, khusus menjelaskan tentang bangsa Berber di Afrika Utara. Ibn Khaldun, Mugaddimah, h. 17. Jadi Mugaddimah adalah ga-bungan antara Pendahuluan dan 3 Jilid itu.

8. Nama lengkapnya sebagaimana disebutkan dalam Mugaddimah adalah Abd al-Rahman ibn Muhammad ibn Khaldun al-Hadrami. Masyarakat yang hidup sejaman dengannya banyak memberi pujian yang panjang, antara lain Qadhi al-Qudhat Wali al-Din Abu Zaid Abdul Rahman ibn Syaikh al-Imam Abu Abdillah Muhammad ibn Khaldun alHadrami al-Maliki. Beliau dikenal dengan panggilan Ibn Khaldun dikaitkan dengan garis genealogi kakeknya yang kesembilan, yaitu Khalid ibn Usman. Sebutan Ibn Khaldun disesuaikan dengan tradisi masyarakat Andalusia dan Maghribi, yang menambahkan huruf waw dan nun di belakang nama orang yang terkemuka dan berpenganuh luas sebagai penghormatan dan takeim, seperti Khalid men- 
27.Ibn Khaldun, Mugaddimah, Mesir, Mathba'ah Musthafa Muhammad, t.th., h. 35.

28. Nugroho Notosusanto, Masalah Penelitian Sejarah Kontemporer, Jakarta, Idayu Pres, 1984, Cet. ke-2, h. 10.

29.lbid, h. 11.

30./bid, h. 11-12.

31. Osman Raliby, Ibnu Khaldun tentang Masyarakat dan Negara, Jakarta, Bulan Bintang, 1978, Cet. ke-4, h. 41.

32.Abul Fotouh Muhammad alTawansy, "Ibn Khaldun", Studies in Islam Series, No. 5, Cairo, The Supreme Council for Islamic Affairs, 1967, $3^{\text {rd }}$ Edition, h. 25.

33.Ibn Khaldun, op. cit., h.11.

34. Ibid, h. 37.

35. Ibid, h. 37.

36. Ibid, h. 37.

37. Muhsin Mahdi, Ibn Khaldun's Philosophy of History, A Study in The Philosophic Foundation of The Science of Culture, London, George and Unwin Ltd, 1957, h.147.

38. Bid, h. 147

39. Effat al-Sarqawi, op. cit., h. 332.

40.Muhsin Mahdi, op. cit., h. 155.

41.Jbid, h.155.

42. Kelihatannya di sini Ibn Khaldun sependapat dengan ahli Hadis ortodoks, bahwa bagaimanapun Islam memperhatikan semua aktivitas manusia dan karena itu tidak membagi secara tegas antara urusan agama dan dunia. Mereka cenderung mengajukan data historis secara sama seperti ketika mereka mengemukakan Hadis-Hadis nabi Muhammad saw. Sebaliknya dia menekankan perlunya pertedaan antara ke-giatan dunia dan keagamaan, yang masing-masing memillki ke-khususan tersendiri yang berbeda satu sama lainnya.

43. Fuad Baali dan Ali Wardi, Ibn Khaldun and Islamic ThoughtStyles A Social Perspective, USA, G. K. Hall and Co. Bston, 1981, h.107.

44.Muhsin Mahdi, op. cit., h. 155.

45. Effat al-Sarqawi, op. cit., h. 333

46.Muhsin Mahdi, op. cit., h. 155.

47. Franz Rosenthal, $A$ History of Muslim Historiography, Leiden, E.J. Brill, 1952, h. 104

48.lbid, h. 104.

49.Ahmadi Toha menerjemahkan mazhab sebagai metode (cara atau jalan). Lihat terjemahan Mukaddimahnya, Jakarta, Pustaka Firdaus, 1986, h. 12. F. Rosenthal mengartikannya dengan pendekatan (approach). Lihat terjemahan dalam bahasa Inggrisnya, The Mukaddi-mah... h.15. Menurut Franz, bahwa penulisan sejarah dapat menggunakan berbagai disiplin ilmu (multidiscipline approachest.

50.Ibn Khaldun, op. cit., h. 9.

51. Bid, h. 35.

52. Jbid, h. 35.

53.Zainab al-Khudhairi, op. cit., h. 47.

54.Ibn Khaldun menyadari betapa pentingnya metodologi yang disebut Weber dengan Vesstehen dalam mempelajari fenomena sosial. Jika penelaah tidak memahami sepenuhnya tujuan pelaku sejarah, maka dia tidak me. mahami arti sebenarnya dari tindakannya.

55.Ibn Khaldun, op. cit., h. 35.

56. Ibid, h. 35.

57. Ibid, h. 35. 
58.Zainab al-Khudhairl, op. cit., h. 47.

59.Ibn Khaldun, op. cit., h. 35.

60. Karena menganalisis sebab ke-7 inilah Ibn Khaldun menjadi terkenal. Seluruh teori sosiologinya dikemukakan untuk menunjukkan bagaimana kebohongan atau kekeliruan bisa dilakukan tanpa sengaja sebagai akibat mengabaikan hukum-hukum peradaban atau pergaulan manusia. Fuad Baali dan Ali Wardi, op. cit., h. 106.

61.Ibn Khaldun, op. cit., h. 35-36.

62. Ibid, h. 9-10.

63. lbid, h. 25 dan 29.

64. Ibid, h. 37.

65. Aziz al-Azmeh, Ibn Khaldun in Modern Scholarship, A Study in Orientalism, London, $3^{\text {rd }}$ World Centre for Research and Publication, 1981, Cet. ke-1, h. 6.

66. Ali Abdul Wahid Wafi, op. cit., h. 96-97.

67. Ibid, h. 97.

68. Muharnmad Abdullah Enan, op. cit., h. 82.

69.Ibn Khaldun, op. cit., h. 35.

70. Muhammad Abdullah Enan, op. cit., h. 81.

71.Jbid, h. 81.

72. Ibid, h. 81 .

73.Ali Abdul Wahid Wafi, op. cit. h. 95.

74. Ibid, h. 95.

75. Muhammad Abdullah Enan, op. cit., h. 82.

\section{Daftar Pustaka}

Abdullah; Taufik dan Abdurrahman Surjomiharadjo, (eds.), Ilmu Sejarah dan Historiografi:
Arah dan Perspektif, Jakarta, Gramedia, 1985.

al-Azmeh, Aziz, Ibn Khaldun in Modem Scholarship, A Study in Orientalism, London, $3^{\text {rd }}$ World Centre for Research and Pu-blication, 1981, Cet. ke-1.

al-Husri, Syathi', Dirasāt an Mugaddimah Ion Khaldun, Mesir, Mathba'ah al-Khanjil, 1961.

al-Khudairi, Zainab, Filsafat Sejarah Ibn Khaldun, Bandung Pustaka, 1987, Cet. ke-1.

al-Sarqawi, Effat, Filsafat Kebudayaan Islam, terj. Ahmad Rofi Utsmani, Bandung, Pustaka, 1986, Cet. ke-1.

al-Tawansy, Abul Fotouh Muhammad, Ibn Khaldun, Studies in Islam Serles, No. 5, Cairo, The Supreme Council for Islamic Affairs, 1967.

Baali, Fuadi dan Ali Wardi, Ibn - Khaldun and Islamic Thought Styles A Social Perspective, USA, G. K. Hall and Co. Boston, 1981.

Cassirer, Emst, Manusia dan Kebudayaan: Sebuah Esei tentang Manusla, terj. Alois A. Nugroho, Jakarta, Gramedia, 1990.

Enan, Muhammad Abdullah, Ibn Khaldun His Life and His Work, Lahore, Syaikh Muhammad Ashraf, 1946.

Gazalba, Sidi, Pengantar Sejarah Sebagai Ilmu, Jakarta, Bharata, 1966.

Ibn Khaldun, Kitäb al- /bar wa Diwän al-Mubta-da' wa al-Khabar fi Ayyàm al-'Arab wa al- Ajam wa al-Barbar wa Man - Asarahum min Dzawi alSuitän al-Akbar. 
Ibn Khaldun, Mugaddimah, Mesir, Mathba'ah Musthafa Muhammad, t.th.

Kartodirdjo, Sartono, Pendekatan IImu Sosial dalam Metodologi Sejarah, Jakarta, Gramedia, 1992.

Kuntowijoyo, Paradigma Islam Inter-pretasi untuk Aksi, Bandung, Mizan, 1991, Cet. ke-1.

Lewis, Bemard, et.al.,(eds.). The Encyclopaedia of Lslam. Leiden, E. J. Brill, Vol. 3.

Madjid, Nurcholish, Islam Kemoderenan dan Keindoneslaan, Bandung, Mizan, 1987.

Mahdi, Muhsin, Ibn Khaldun's Philosophy of History. A Study in The Philosophic Foundation of The Science of Cultu$r e$, London, George and Unwin Ltd, 1957.

Muththahhari,Murtadha, Masyarakat dan Sejarah, Kritik Islam atas Marxisme dan Teori Lainnya, Bandung. Mizan, 1990

Notosusanto, Nugroho, Masalah Penelitian Sejarah Kontemporer, Jakarta, Idayu Pres, 1984.

Peursen, C. A. van, Fakta, Nilai, Peristiua, terj. A. Sonny Keraf, Jakarta, Gramedia, 1990.

Raliby. Osman, Ionu Khaldun tentang Masyarakat dan Negara, Jakarta, Bulan Bintang, 1978.
Rosenthal, Franz, A History of Muslim Historiography, Leiden, E. J. Brill, 1952.

Rosenthal, Franz, Book of Lessons and Archive of Early and Subsequent History, Dealing with the Political Events Conceming the Arabs, Non Arabs, and Berbers, and the Supreme Rulers Who Were Contemporery with Them.

Rosenthal, Franz, The Mukaddimah, London, Routlege and Kegan Paul, 1958, Cet. ke-1, Vol. 1.

Seminar Nasional Sastra dan Sejarah Pajajaran, Bogor, 11 Nopember 1991.

Toha, Ahmadi, Mukaddimah, Jakarta, Pustaka Firdaus, 1986.

Toynbee, Amold J., A Study of History, London, Oxford University Press, 1948, Vol. 3.

Utsman, Hasan, Manhaj al-Bahs alTänkhí, Mesir, Dar al-Ma'arif, 1970.

Wafi. Ali Abdul Wahid, Ibn Khaldun: Riwayat Hidup dan Karyanya, Jakarta, Grafiti Pers, 1985. Cet. ke-1.

Zainudin, A. Rahman, Kekuasaan dan Negara: Pemikiran Politik Ibn Khaldun, Jakarta, Gramedia, 1992, Cet. ke-1. 